\title{
The Effect of Core Learning Model on Students' Metacognitive Skills in Lipid Material
}

\author{
Rindi Novitri Antika ${ }^{1}$ \\ ${ }^{1}$ Biology Education, Universitas Muhammadiyah Palembang, Indonesia \\ St. Jend. A. Yani 13 Ulu Palembang. 30263. \\ Corresponding Author. E-mail: \\ ${ }^{1}$ rindi.ump@gmail.com \\ Received: December 28 ${ }^{\text {th }}, 2019$ \\ Accepted: January 28 ${ }^{\text {th }}, 2020$ Online Published: January 31 ${ }^{\text {st }}, 2020$
}

\begin{abstract}
Metacognitive is one of the important factors must have by student. This study aims to determine the effect of the CORE (Connecting, Organizing, Reflecting, and Extending) learning model on students' metacognitive sklills and find out the students' responses about it's implementation. This research is a preexperimental study with one group pretest-posttest design. The subject of this study was grade 3rd of biology education students. The instrument in this study is an essay and metacognition descriptor rubric to assess students' metacognitive skill, then questionnaires to obtain data on student responses that implemented the CORE learning model. Based on the results of the paired sample $t$ test on student metacognition scores obtained sig. $0.00<0.05$, it means that there are differences between the results of the student's pretest and posttest. Then, based on $\mathrm{N}$-gain analysis pretest and posttest data, it is known that the $\mathrm{N}$-gain value is 0.71 , it's means high increase category,. Then the result of pearson correlation test to analyze correlation between cognitive learning outcomes and student metacognitive skills obtained sig. 0,00 , it means that there was a correlation between the two of them. Based on some of these analyzes it can be concluded that the CORE learning model influences students' metacognitive skills on lipid material. This was supported by the results of a questionnaire showed that students gave positive responses about the application of the CORE learning model, it was known from questionnaire data, more than $85 \%$ of students felt the CORE model had a positive impact on learning.
\end{abstract}

Keywords: CORE; lipid; metacognitive skill

How to cite this article :

Antika, R. N. (2020). The Effect of Core Learning Model on Students' Metacognitive Skills in Lipid Material. IJIS Edu : Indonesian Journal of Integrated Science Education, 2(1), 35-42. doi:http://dx.doi.org/10.29300/ijisedu.v2i1.2609 


\section{INTRODUCTION}

The globalization era requires quality of human resources that are able to compete not only in formal education, but more importantly is the skills to exist in the work. One of the skills that must be have to be able to compete in the global world is metacognitive skill. The study conducted by Chun Yi Shen \& Hsiu Cuan Liu (2011) on 179 research subjects stated that metacognition was ranked first of 200 factors that influence learning outcomes. The government has made policies in the field of higher education to establish human resources that have global competitiveness. One such effort is the publication of the Kerangka Kurikulum Nasional Indonesia (KKNI) which is a qualification framework that can equalize and integrate learning outcomes from non-formal education, informal education, and/ or work experience into higher education types and levels. Therefore, educational institutions are not enough to yield graduates with a certain degree, but must have skills that can be used for their lives.

The biology learning process is not fully in accordance with the nature of learning science. Nowadays, learning in the class only prioritizes products, so that the learning process tends to be lecturer centered. This resulted the metacognitive skills of students not being trained. Some studies show the low metacognitive skills of students. Research of Amrulloh and Ardhi (2017) states that based on the identification of metacognition skills using an integrated essay test, it is known that biology education students at the University of PGRI Madiun have metacognitive skills in category at risk $(30.5 \%)$, not really $(38.8 \%)$ and developing $(30.5 \%)$, no one has reached the OK and Super categories. Then Paidi, Wibowo, Rahmawati (2013) also conducted a study on the analysis of the metacognitive abilities of UNY biology education students with the results of research showing that the development of metacognitive skills of Biology Education students was not optimal, the result of average metacognition capability is 69.98, which developed just metacognitive knowledge especially the declarative aspects knowledge.

Biochemistry is one of the subjects that learn about chemical reactions or molecular interactions in living cells. The purpose of studying biochemistry is to study and find out how the structures that make up living organisms interact with one another to maintain and sustain life. One material that must be studied is the subject of lipids. In this material we learn about the structure, mechanism or process of anabolism and catabolism, diseases and abnormalities associated with lipids, and efforts to prevent the disease. Lipid material is contextual, much related to everyday life, so it is familiar to students. Many problematic problems can be identified in lipid material as examples is abnormalities of lipid metabolism, vascular abnormalities, and others. Therefore, this course requires students to be able to understand, analyze, and link functions, lipid metabolic processes, and self-regulation to prevent disturbances in the body using metacognitive skills.

One of learning model that has the potential to train student metacognitive skills is the CORE model. The CORE model is a learning model that uses discussion methods that can influence the development of knowledge and reflective thinking by involving students who have four stages of teaching, among them Connecting, Organizing, Reflecting, and Extending. Calfee et al. (2010) revealed that CORE learning model is a learning model that expects students to be able to construct their own knowledge, able to plan, monitor, and evaluate the learning outcomes. Based on this background, the researcher intends to conduct a study entitled the influence of the CORE model on student metacognitive abilities in lipid material.

\section{RESEARCH METHOD}

This research is a pre-experimental study with group design pretest-posttest. The subject of study was the 3rd grade semester students of Biology Education Department of the University of Muhammadiyah Palembang selected by total sampling technique. In collecting data, the researchers used the results of the pretest, posttest and the questionaire. The pretest and posttest data obtained were then analyzed by calculating the normalized gain ( $\mathrm{n}$ gain) to see how high the increase occurred. Then the normality, homogeneity and t-test paired tests were conducted to see the difference between students' metacognitive abilities on the pretest and posttest. In addition, a correlation test was conducted to analyze the relationship between cognitive learning outcomes and metacognitive abilities. 


\section{RESULTS AND DISCUSSION}

\section{A. Metacognitive Skill}

Pretest and posttest are consist of 8 essay questions which is integrated with descriptors of metacognitive skill by Corebima (2007). Summary of the result aspects of student metacognition skills shows in table 1.

Table 1. Summary of the students' metacognitive skills

\begin{tabular}{ccccc}
\hline $\begin{array}{c}\text { Student } \\
\text { Learning } \\
\begin{array}{c}\text { Outcome } \\
\text { Metacog } \\
\text { nitive } \\
\text { Skills) }\end{array}\end{array}$ & $\begin{array}{c}\text { Data } \\
\text { Maximu }\end{array}$ & $\begin{array}{c}\text { Data } \\
\text { Minimu } \\
\mathrm{m}\end{array}$ & $\begin{array}{c}\text { Avera } \\
\text { ge }\end{array}$ & $\begin{array}{c}\text { Deviatio } \\
\mathrm{n}\end{array}$ \\
\hline Pre-test & 44,42 & 11,25 & 22,52 & 7,42 \\
\hline Post-test & 94,25 & 58,0 & 77,37 & 8,02 \\
\hline N-gain & 1,00 & 0,00 & 0,71 & 0,10 \\
\hline
\end{tabular}

Based on Table 1, it showed that the average metacognitive skills before learning is 22.52 which indicates that is in the low category. After learning with the CORE (Connecting Organizing Reflecting and Extending) model, the average student learning outcomes became 77.37 in the high category. The pre-test and post-test values are then calculated for improvement. The formula used is the normalized gain formula. Based on the results of the $\mathrm{N}$-gain calculation, the average is 0.71 . According to Hake's criteria (1999) the value shows that there is increase in student learning outcomes in the high category.

Based on the data obtained, then researcer did a statistical test. The prerequisite test is done by calculating the normality of the pre-test and post-test data, then further testing was the paired t test. A summary of the results of the pre-test and post-test is showed in Table 2.
Table 2. Summary of Metacognitive skill Test

\begin{tabular}{cccc}
\hline $\begin{array}{c}\text { Learning } \\
\text { Outcomes } \\
\text { (Metacognitive } \\
\text { skills) }\end{array}$ & $\begin{array}{c}\text { Test of } \\
\text { Normality } \\
\text { (Sig) }\end{array}$ & $\begin{array}{c}\text { Homogeneity } \\
\text { Test (Sig) }\end{array}$ & $\begin{array}{c}\text { Paired } \\
\text { Sample } \\
\text { t Test } \\
\text { (Sig) }\end{array}$ \\
\hline Pretest & $\begin{array}{c}0,187> \\
0,05\end{array}$ & & \\
\cline { 1 - 2 } Postest & $0,0,091>0,05$ & $0,00<$ \\
& 0,05 & & 0,05 \\
\hline
\end{tabular}

Based on table 2 known that there are differences between the results of pretest and posttest, then because student learning outcomes at the posttest are higher than the pretest shown that $\mathrm{N}$-gain is high category, it can be concluded that there is a significant effect of CORE learning models on students' metacognitive skills. Further analysis was carried out by analyzed the different categories of metacognitive skills of students before and after learning. The results showed the analysis per level of the category of metacognition are available in table 3 .

Table 3. Percentage of Student Metacognition Skills Categories

\begin{tabular}{lrr}
$\begin{array}{c}\text { Level } \\
\text { Categories }\end{array}$ & \multicolumn{1}{c}{$\begin{array}{c}\text { Pre-test } \\
(\mathbf{\%})\end{array}$} & \multicolumn{1}{c}{ Post-Test (\%) } \\
\hline Not Yet & 20 & 0 \\
\hline At Risk & 73,33 & 0 \\
\hline Not Really & 6,67 & 0 \\
\hline Developing & 0 & 13,33 \\
\hline OK & 0 & 73,33 \\
\hline Super & 0 & 13,34
\end{tabular}

Based on table 3, it can be seen that students' metacognitive skills before learning is measured by pretest, mostly in the At Risk category, which does not seem to have the awareness of thinking as a process, the rest in the Not Yet and Not Really categories that have not been exposed to metacognitive and not able to separate what he thinks about how he thinks. While the ability of metacognitive after learning measured using posttest is known to increase significantly. Most students have the metacognitive skills at the level of $O K$, that is, conscious of thinking on their own and being able to distinguish between the stages of inputelaboration-output of his own mind, sometimes using models to regulate his own thinking and 
learning. Another students have metacognitive skills in category of Developing and Super, which can help towards awareness of self-thinking if encouraged and supported and use metacognitive awareness regularly to regulate the process of thinking and learning itself, realizing there are many kinds of possibilities of thinking, able to use smoothly and reflect the thinking .

\section{B. Correlation between Cognitive Learning Outcomes and Student Metacognitive Skills}

After analyzing the increase in student metacognitive skills, an analysis of the relationship between cognitive learning outcomes and student metacognition abilities was conducted. The test results are presented in table 3.

Tabel 3. Correlation between Cognitive Learning Outcomes and Student Metacognitive Skills

\begin{tabular}{|l|l|r|r|}
\hline \multicolumn{2}{|c|}{} & $\begin{array}{r}\text { Cognitive } \\
\text { Cogetacognit } \\
\text { ive }\end{array}$ \\
\hline \multirow{3}{*}{ Cognitive } & $\begin{array}{l}\text { Pearson } \\
\text { Correlation }\end{array}$ & 1 &, $775^{* *}$ \\
\cline { 2 - 4 } & Sig. (2-tailed) & &, 000 \\
\hline \multirow{3}{*}{ Metacognitive } & $\begin{array}{l}\text { Pearson } \\
\text { Correlation }\end{array}$ &, $775^{* *}$ & 1 \\
\cline { 2 - 4 } & Sig. (2-tailed) &, 000 & \\
\hline
\end{tabular}

Based on the results of the correlation test that has been done, it is known that sig $0,000<0,05$ means that there is a relationship between the value of cognitive learning outcomes of students with their metacognitive skills. This is also supported by the Pearson Correlation value of 0.775 . The higher the metacognition ability of students, the higher the learning outcomes they obtain. This is because metacognition is one of the important factors that students must have to be able to complete learning targets. These results are in accordance with the research conducted by Ardila (2012), where the research conducted obtained the results of a relationship between students' metacognitive skills in the application of PBMP strategies. The research is also in line with the research conducted by Singh (2012) which shows that the correlation between metacognitive skills and learning outcomes in science lessons grade XI students are positive and significant.

The other study about the relationship between metacognitive abilities and cognitive learning outcomes was revealed by Aisyah and Ridho (2015) who had a strong positive relationship between metacognitive skills and cognitive learning outcomes. Furthermore, Patonah (2014) also stated that metacognitive is very necessary for the success of learning, because metacognitive allows students to be able to manage cognitive skills and be able to see (find) their weaknesses which will be improved with subsequent cognitive skills. This statement was supported by Mandobar (2013) who stated that the ability of metacognition has a positive relationship with learning outcomes, namely students who have high metacognitive abilities show better learning outcomes compared to students who have low metacognition. Matlin (2003), states that metacognition is our knowledge, awareness, and control of our cognitive processes. Furthermore Matlin said that metacognition is very important in helping us regulate the environment and select strategies to improve our cognitive abilities later

Schraw \& Dennison (Panaoura \& Philippou, 2007) affirms the ability of metacognition to also manifest as self reflection, self monitoring, or self awareness and learning activities that have been carried out. The ability of metacognition is related to controlling cognitive components that allow students to understand the task or problem at hand, then try to ensure that all tasks or problems are resolved correctly. When working on assignments, students who have high metacognition skills, not only think about completing assignments, but they will always evaluate themselves to make confidence that the task or problem given has been resolved properly and correctly.

Before study, students had already been formed in heterogeneous groups. Groups are organized based on differences in thinking skills. This is intended so that there are mutual learning activities between underachievement students (students with low thinking skills) and students with high thinking skills. These considerations are based on the statement of Vygotsky (in Taylor, 1993) that students in constructing a concept need to pay attention to the social environment. There are two important concepts in Vygotsky's theory, namely Zone of Proximal Development (ZPD) and scaffolding. Zone of Proximal Development (ZPD) is the distance between the level of actual development which is defined as the ability to solve problems independently and the level of potential development that is defined as 
problem solving ability under adult guidance or through collaboration with more capable colleagues. Scaffolding is the provision of a number of assistance to students during the early stages of learning, then reducing assistance and providing an opportunity to take on greater responsibilities after he can do so. Scaffolding in this study is assistance provided by group members to other members (student underachievement) in one group to study, solve problems, or form concepts.

This activity has the potential to have an impact on the training of student metacognition skills to developing criteria, which can help towards awareness of self-thinking if encouraged and supported. This ability is trained from group discussion activities conducted by considering heterogeneous collaborative teams. This opinion is supported by the expression of Slavin (2005) which states that student behaviors that arise in collaborative groups such as cognitive expansion, peer teaching, modeling by friends, motivation to help group friends to learn, and justification and correction for friends are proven to improve achievement study top academic ability students or under-academic students.

The CORE model begins with Connecting activity, that was do by connecting old information or relating to daily life and new information. This activity is carried out by giving questions such as "when we fast, where can we get energy sources?" even though we don't consume anything ". This question is given to explore the students' initial knowledge about the material to be learned. Astuti (2015) which states that initial knowledge is the main factor that will affect the learning experience for students. Initial knowledge is very important role in increasing the meaningfulness of teaching.

Connecting activities train students' metacognitive skills, namely information management abilities. In the Connecting phase this is also done by asking students about what is the same between fat and oil. All students have different answers to their respective arguments. Giving this second question intends to cause cognitive conflict in the minds of students. The differences of opinion they experience will make them motivated to get the real answers. The student's initial conception may be right or wrong. Cognitive conflict in the minds of students is an important stage in learning so that cognitive imbalances arise. This cognitive imbalance will make students think about strategies to solve conflicts in their minds so that students practice their metacogical abilities. As revealed by Piaget (in Jauhar, 2011) cognitive imbalances will lead to assimilation and accommodation in the minds of students.

The second step in CORE syntax is organizing. The Organizing Stage is an activity to produce ideas to understand material. At this stage students are asked to design a study of lipids. Based on the questions on the connecting stage, students made a research design. The research design made by the student group contained direct practice activities to find out the general characteristics of fat and oil, some of which contained interviews with experts, some contained literature study activities by preparing several questions to solve. Research conducted by students begins with formulating a problem statement as a direction for carrying out activities. At this stage the lecturer acts as a consultant and guides the formulation of the problem so that the learning activities are carried out in accordance with the learning objectives that have been prepared. After ripe to formulate the problem statement, students make hypotheses and design activities in the form of tools and materials needed as well as steps that need to be implemented.

This Organizing activity trains students' metacognition skills up to the OK category, which is to consciously think on their own and be able to distinguish between the stages of their own input-elaboration-outputs, and sometimes using models to regulate their own thinking and learning. It was trained with discussion activities that began with differences of opinion between students. The process continues until students get a solution to the problem they wrote. The final answer obtained will place students at a higher level of knowledge. Posner (1992) and Hewson (1989) which state that conceptual changes in the minds of students occur first that students must feel dissatisfied with the ideas. So with this dissatisfaction students will find out the truth, in the process students will use their metacognised abilities until they find the most appropriate way to do problem solving. The third stage is reflecting, which is the activity of rethinking, exploring, and digging for information that has been obtained. This stage is carried out by making presentations in front of the class to get suggestions and criticisms from the audience and lecturers about the solutions obtained by the team when studying, as well as self-assessment conducted by the group 
regarding the settlement of problems that have been prepared, timeliness of completion, accuracy of completion methods, media and so forth. This reflecting stage trains students' metacognitive abilities up to the super category of using metacognitive awareness on a regular basis to regulate their own thinking and learning processes and realize there are many kinds of thinking possibilities, able to use them smoothly and reflect their thinking processes. This is supported by the statement of Kazemi, Yektayar, \& Abad (2012) People who have a high level of metacognitive skills make problem solving better to know the relationship between facts and problems, in line with Baten, Praet, \& Desoete (2017) which states that through skills metacognitive, every child can plan and manage time, choose the right strategy and provide understanding in learning, and monitor the progress of learning by reflecting on the use of strategies and the effectiveness of solutions and self-reflection of each student in solving problems.

The last step in the CORE learning model is extending. Extending is the stage where students expand the knowledge gained during the learning process. The expansion of knowledge referred to in this process is carried out by applying the concepts that have been obtained into different contexts. In discussion activities, students are expected to be able to expand knowledge by working on questions related to the concepts learned but in new situations or different contexts in groups. To solve this problem students need mastery about the strategy of how to solve, what is needed to solve it, and what if the solution that has been done is wrong. If you have achieved these things, it means that students have achieved a super metacognitive ability that is able to use metacognitive awareness on a regular basis to regulate their own thinking and learning processes and realize there are many kinds of possibilities for thinking, able to use them smoothly and reflect their thinking processes. The results of this study are supported by the statement of Corebima (2006) which explains that the skill sets involved in metacognition are three, namely 1) the skills to understand the strategy, or what and so on resources needed to do a task; 2) skills to know how to use what strategies or sources and so on; and 3) the skill of knowing when to use the strategy or source and so on.

\section{Responses of the CORE Model}

After learning with the CORE model, the researcher took the student response data about the learning process carried out with the CORE model. Questionnaires consist of 6 positive statement items and 5 negative statement items. The results of the full questionnaire analysis can be seen in Figure 1.

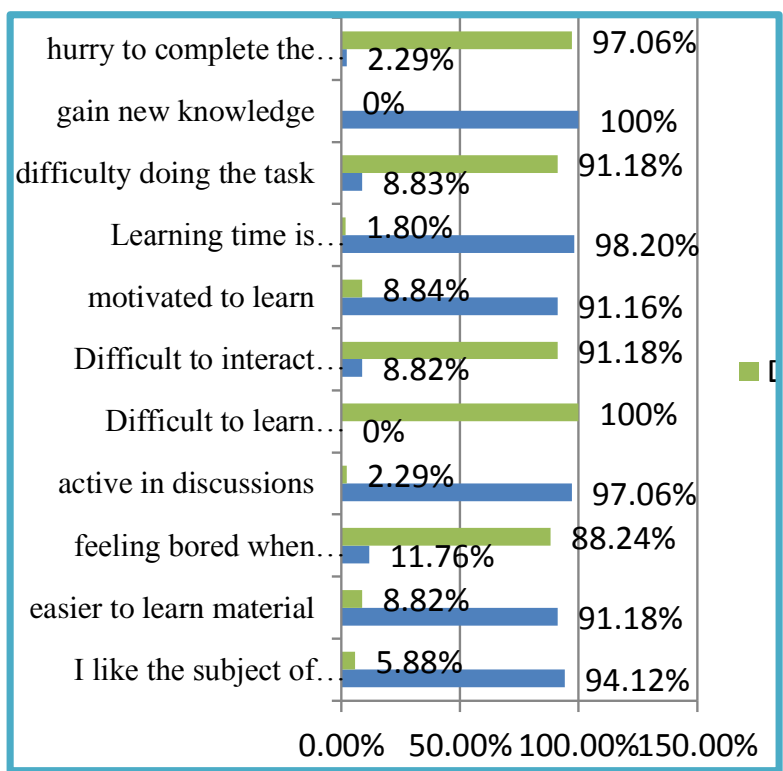

Figure 1 Results of the CORE Model Implementation Questionnaire

Based on Figure 1, A is for "agree" and D is for "disagree". It is known that most students answer agree on items that are positive statements and most also answer disagree on items negative statements. This indicates that there is a positive response to the use of the CORE model for lipid material. Most respondents felt that applying this model facilitated mastery of concepts, especially lipid material. This can be seen from data that states that over $85 \%$ of students feel that 1) they get new insights, meaning that they get meaningful learning so that they gain more experience; 2) the time used is in accordance with needs, so that no material is missed, meaning that the CORE learning model is effective in dealing with short study time in class; 3) motivated to explore new experiences, in this learning model there is a reflecting stage that allows students to evaluate their achievement both the achievement of the target, the expected time, and the lack of steps to complete the task, so that they are more motivated to seek more experience than before; 
4) feeling more active in discussions, heterogeneous discussion groups that make students learn from each other, highly capable students share their knowledge with students with low abilities. In addition, each student is required to make a presentation at the organizing stage; 5) easier to master the material, meaning that the scaffolding provided by his group friends is successful.

This also happened to negative statements given to students. In general, under $15 \%$ of students feel 1) hurry to complete assignments, 2) Difficulty working on activities, 3) difficulty interacting with friends, 4) difficulty learning the material, and 5) feeling bored in learning. The results of this questionnaire are supported by the statement of Pierce (2003) which explains that metacognition influences student learning motivation. Furthermore, it was explained that the more often students are aware of their thinking processes when they study, the more they will be able to control their goals, personality, and attention. If students are not good at carrying out monitoring activities, it will certainly make it difficult for students to understand the material being taught.

Based on the questionnaire the results obtained outline that students who use the CORE model have high learning motivation. Motivation is characterized by positive reactions or pleasant feelings when carrying out learning, because motivation relates to a goal. This is supported by the opinion of Sardiman (1996: 75) argues, Motivation to learn is a psychological factor that is non-intellectual. Its distinctive role is in terms of growing passion, feeling happy and passion for learning. Students who have strong motivation will have a lot of energy to carry out learning activities. A student who despite having high enough intelligence can be a failure if the motivation in him is lacking. Uno (2008) says that learning motivation consists of six aspects, namely 1) desire and desire succeed; 2) the existence of encouragement and learning needs; 3) the existence of hopes and ideals; 4) appreciation in learning; 5) interesting activities in learning; 6) the existence of a conducive learning environment.

\section{CONCLUSION}

From the study, researcer conclude that the CORE learning model influences students' metacognition abilities on lipid material, it is known from the results of paired test sig is
$0.00<0.05$ and the results of $\mathrm{N}$-gain analysis between pretest and posttest are 0.7 . There is a strong relationship between cognitive learning outcomes and student metacognition abilities as evidenced by the results of the Pearson Corelation test with sig. 0.00 and pearson correlation 0.775. Beside that, Students given positive responses about application of the CORE learning model, it is known from questionnaire data of more than $85 \%$ of students feel the CORE model has a positive impact on learning.

\section{REFERENCES}

Aisyah, Siti dan Syaiful Ridho. (2015). Pengaruh Strategi Pembelajaran Jigsaw Dan Problem Based Learning Terhadap Skor Keterampilan Metakognitif Siswa Pada Mata Pelajaran Biologi. Unnes J.Biol.Educ. 4 (1)

Amrulloh, A., \& Ardhi, M. W. (2017). Identifikasi Kemampuan Metakognisi pada Mata Kuliah Bilogi Sel Mahasiswa Program Studi Pendidikan Biologi. Prosiding Seminar Nasional, 104-113.Astuti, S. P. (2015). Pengaruh Kemampuan Awal dan Minat Belajar terhadap Prestasi Belajar Fisika. Jurnal Formatif, 5(1) , 68-75

Baten, E., Praet, M., \& Desoete, A. (2017). The Relevance and Efficacy of Metacognition for Insructional Design in the Domain of Mahematics. ZDM, 49(4), 613-623.

Cahyani, Ardila, A.D Corebima, dan Siti Zubaidah. (2012). Hubungan Keterampilan Metakognitif terhadap Hasil Belajar Kognitif dan Retensi Siswa Kelas X dengan Penerapan Strategi Pemberdayaan Berpikir Melalui Pertanyaan (PBMP) di SMA N 9 Malang. (Penelitian). Malang: FMIPA UM

Chun, Y. S., \& Hsiu, C. L. (2011). Metacognitive Skills Development. A Web-Based Approach in Higher Education. The Turkish Online Jurnal Of Education Technology , Volume.10. 
Corebima, A. D. (2007). Metacognitive Skill Measurement Integrated In Achievement Test. Journal Universitas Malang .

Hake, R. R. (1999). Analyzing Change/Gain Scores. februari 22, 2019, retrieved from http://www.phisycs.indiana.edu/sdi/AnalyzingChange-Gain.pdf

Jauhar, M. (2011). Implementasi Pakem dari Behavioristik Sampai Konstruktvistik. Jakarta: Prestasi Pustaka.

Kazemi, J. A., Yektayar, M., \& Abad, A. M. (2012). Investigation The Impact of Chess Play on Developing MetaCognitive Ability and Math ProblemSolving Power of Students at Different Levels of Education. Procedia-Social and Behavioral Sciences. Vol 32, 372-379.

Paidi et al. (2013). Analisis Tingkat Kemampuan Metakognitif Mahasiswa Jurusan Pendidikan Biologi, FMIPA UNY. Prosiding Seminar Nasional Biologi UNY.

Patonah, S. (2014). Elemen Bernalar Tujuan pada Pembelajaran IPA Melalui Pendekatan Metakognitif Siswa SMP. JPII 3 (2) 128-133.

Pierce, W. (2003). Metacognition: Study Strategies, Monitoring, and Motivation. A Greatly Expanded Text Version of a Prince Gorge's Community College. (Online). retrieved September 25, 2018, dari : http://www.merel.org/PDF/Instruction /5982RR_InstructionMeta_Analysis.pdf)

Posner, e. a. (1982). Accomodation od Scientific Conseption: Toward a Teory of Conceptual Change. Scence Education. Vol. 66, 22-221. with Academic Achievement in Science Subject. International Indexed \& Refered Research Journal (IV).

Slavin, R. E. (2005). Cooperative Learning: Theory, Research, and Practive. London: Allen and Bacon.

Uno, H. B. (2008). Pengaruh Penerapan Model Pembelajaran dan Motivasi Belajar terhadap Hasil Belajar Siswa pada Mata Pelajaran IPS di SMP Negeri Model Terpadu Madani PALU. Jurnal Katalogis, Vol. 4 No. 7, 205-214.

Singh, Y.G. 2012. Metacognitive Ability of Secondary Students and Its Association 